
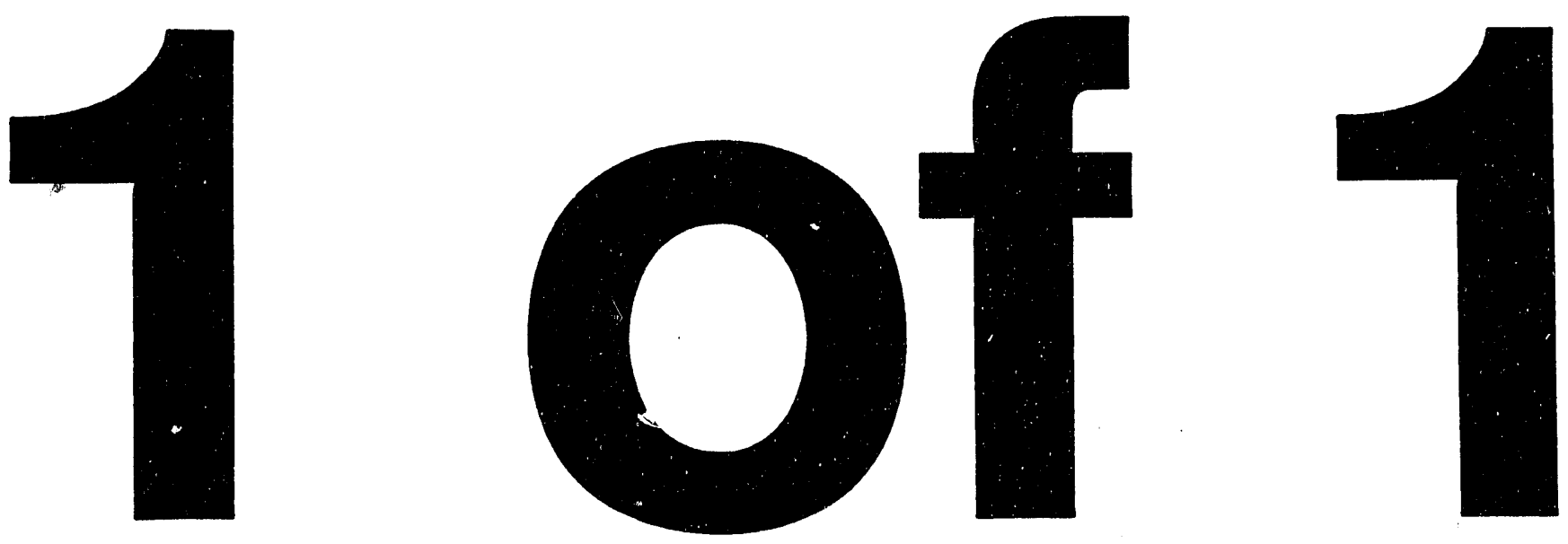
DOE/RL-94-52

UC-513

\section{High-Activity Liquid Packaging Design Criteria}

Date Published

May 1994

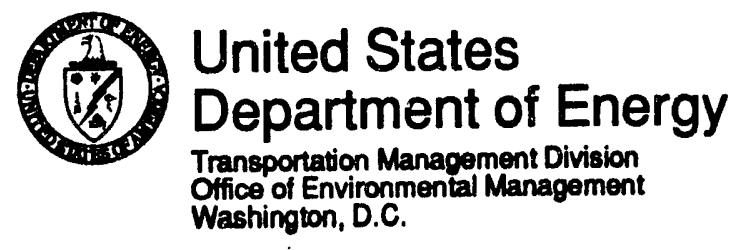

Approved for Public Release 


\section{EXECUTIVE SUMMARY}

There is an apparent need to ship single- and multiple-tank specimens to offsite laboratories. It is possible that the volume and number of samples will inundate the onsite laboratory capabilities at the Hanford Site. Specimen testing is necessary to support characterization of defense by-product liquid waste stored in underground tanks, and to facilitate the pretreatment/vitrification process development (waste disposal) at the Site and possibly at other U.S. Department of Energy sites. Presentiy, no certified Type-B packagings are available for transport of high-activity liquid radioactive specimens in sizes to support Site missions.

This preliminary Packaging Design Criteria provides an explanation of a design concept that uses a U.S. Nuclear Regulatory Commission or U.S. Department of Energy licensed waste or spent fuel cask, which is retrofitted for the offsite shipment of tank liquid specimens. Where possible, this Packaging Design Criteria provides current information on the subject, or addresses the information being sought for the final document. The final Packaging Design Criteria will provide baseline criteria for the High-Activity Liquid Packaging; the purchase or lease of the spent fuel cask system (including cask body, impact limiters, fuel basket, and transport vehicle, if appropriate); and the information needed to prepare an amendment to a cask Safety Analysis Report for Packaging (to be determined). The final Packaging Design Criteria can also be used as a reference document to support the final design services requisition for final design and analysis of the High-Activity Liquid Packaging. 
The completeness of this Packaging Design Criteria depends on two activities that will be completed coincidentally by September 1994. First, a final assessment of the need, establishing the source term and transportation parameters that ensure the right package is being designed, is necessary. Studies are being completed by Westinghouse Hanford Company and other organizations to finalize sampling needs. Second, three reports will be completed: one addressing the most feasible cask for retrofitting, the second addressing liquid source-term identification (including gas generation data), and a third addressing facility/package interface requirements at the transportation endpoints. Once this work has been completed, an amendment to the Packaging Design Criteria can be issued reflecting final packaging design criteria. A revision/amendment to the Safety Analysis Report for Packaging for the cask system (package) chosen for retrofitting will be required to describe and document the new source term and payload configuration. Following U.S. Nuclear Regulatory Commission review and approval of the amended Safety Analysis Report for Packaging, a revision to the Certificate of Compliance will be issued. Offsite shipments of tank waste specimens in the cask may take place only after revision of the Certificate of Compliance is issued. 


\section{CONTENTS}

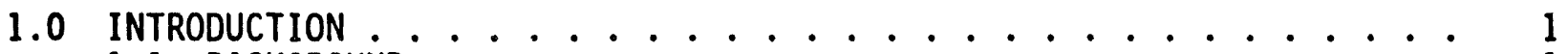

1.1 BACKGROUND ........................ . . . . . 1

1.2 PURPOSE AND SCOPE . . . . . . . . . . . . . . . . 2

1.3 JUSTIFICATION . . . . . . . . . . . . . . . . . . . . 5

2.0 PACKAGE CONTENTS . . . . . . . . . . . . . . . . . 5

2.1 PAYLOAD CONFIGURATION . . . . . . . . . . . . . 5

2.2 PHYSICAL DESCRIPTION .................... . . 6

2.3 RADIONUCLIDE COMPOSITION ................. 6

2.4 FISSILE CLASSIFICATION . . . . . . . . . . . . . 7

2.5 CHEMICAL COMPOSITION ................... 7

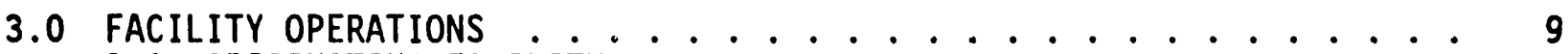

3.1 ORIGINATING FACILITY . . . . . . . . . . . . . . . . 9

3.2 RECEIVING FACILITY . . . . . . . . . . . . . . . . . . . 10

4.0 PACKAGING/TRANSPORT SYSTEM DESIGN CRITERIA . . . . . . . . . . 10

4.1 GENERAL . . . . . . . . . . . . . . . . . . . . 10

4.2 XXX-Y CASK . . . . . . . . . . . . . . . . . . . . . . . . . 10

4.3 CONTAINMENT VESSEL AND SHROUD . . . . . . . . . . . . . . . 11

4.3.1 General Description and Loading Configuration .... 11

4.3.2 Construction Materials ............. 11

4.3.3 Dimensions and Volumes .............. 11

4.3.4 Weight of Contents ............... 11

4.3.5 Closure Design and Venting ............. 11

4.3.6 Shielding ................. 12

4.3.7 Lifting Attachments ............... 12

4.3.8 Gas Mitigation Hardware ..... . . . . . . . . 12

4.3.9 Service Life ................. 12

4.3.10 Decontamination .............. 12

4.4 TRANSPORT SYSTEM ..................... . . . . 12

4.4.1 General ..................... 12

4.4.2 Tiedowns .................... 12

5.0 GENERAL REQUIREMENTS . . . . . . . . . . . . . . . . . 12

5.1 TRANSPORTATION SAFETY . . . . . . . . . . . . . . . 12

5.2 AS LOW AS REASONABLY ACHIEVABLE . . . . . . . . . . . . . . . 13

5.3 QUALITY ASSURANCE ........................ 13

5.4 PACKAGING AND SHIPPING ................... 14

5.5 MAINTENANCE ........................ 14

6.0 REFERENCES . . . . . . . . . . . . . . . . . . 14

7.0 GLOSSARY . . . . . . . . . . . . . . . . 14 


\section{DOE/RL-94-52 \\ Revision 0 \\ LIST OF FIGURES}

1 Proposed High-Activity Liquid Packaging Cask System Configuration . . 3

2 Proposed High-Activity Liquid Packaging Operating Sequence . . . . . . 4

\section{LIST OF TABLES}

1 Physical Characteristics of Waste .............. 7

2 Maximum Radionuclide Source Term . . . . . . . . . . . . 8

3 Maximum Concentrations of Non-Radioactive Materials ....... 9 
DOE/RL-94-52

Revision 0

\section{HIGH-ACTIVITY LIQUID PACKAGING DESIGN CRITERIA}

\subsection{INTRODUCTION}

\subsection{BACKGROUND}

In recent studies, it has been acknowledged that there is an emerging need for packaging to transport high-activity liquid off the Hanford Site to support characterization and process development activities of 1 iquid waste stored in underground tanks. These studies have dealt with specimen testing needs primarily at the Hanford Site; however, similar needs appear to be developing at other U.S. Department of Energy (DOE) sites. The need to ship single and multiple specimens to offsite laboratories is anticipated because it is predicted that onsite laboratories will be overwhelmed by an increasing number and size (volume) of samples. Potentially, the specimen size could range from $250 \mathrm{~mL}$ to greater than $50 \mathrm{~L}$. Presently, no certified Type-B packagings are available for transport of high-activity liquid radioactive specimens in sizes to support Site missions.

The expense and time necessary to design and certify a new Type-B packaging can be substantial. Consequently, it was decided to examine a potentially more cost-effective packaging concept that uses an existing licensed spent fuel or solid waste cask, and retrofits it with a highintegrity containment vessel for radioactive liquid transport. Not licensing a cask system (body, payload, and impact limiters) will enable regulatory authorities to focus on the containment vessel and its contents; however, a cask Safety Analysis Report for Packaging (SARP) (to be determined) will need to be amended to reflect the physical and radiological parameters of the liquid payload. Additionally, retrofitting an existing licensed fuel/waste cask and relicensing for liquid transport extends the service life of a packaging while facilitating restoration and remediation missions at DOE sites. A search for packaging, assessing casks against a common criteria, and recommending casks for High-Activity Liquid Packaging (HALPAK) conversion will be completed in July 1994 .

A Cask Selection Report is scheduled for completion by july 1994. This report will contain a thorough analys is of available licensed cask bodies with specific size and shielding parameters, evaluation criteria to enable an objective comparative analysis of each cask body with the other, and a conclusion with one or two cask bodies/systems recommended for liquid transportation retrofitting. The cask body selected for HALPAK conversion will likely be licensed for Type.-B quantities of solid form irradiated fuel elements or solid form waste, and carry a U.S. Nuclear Regulatory Commission (NRC) Certificate of Compliance (COC).

The cask system (body, basket with payload, and impact limiting system) was originally designed for the structural, thermal, and radiological loads from spent fuel contained in a fuel basket. Because these loads were for a heavier, more radioacti le payload, it is initially assumed that the recommended cask body and impact limiters will have adequate structural strength, thermal transfer capability, and radiological shielding to be 
readily compatible with the liquid payload. Therefore, these same loads, when generated by a liquid loaded containment vessel and shroud, are expected to be smaller than those for which the spent fuel cask system was originally designed. Structural, thermal, shielding, and criticality analyses performed during the final design phase of this project will demonstrate the adequacy of the retrofitted package. The final design Packaging Design Criteria (PDC) will establish the criteria against which the final packaging design will be evaluated.

Figure 1 shows the proposed HALPAK cask system configuration. For the purposes of shipping single- or multiple-tank core specimens, the fuel basket will be replaced with a leak-testable high-integrity containment vessel that is compatible with the tank specimens. The radionuclide and chemical content, volume, and gas generation properties of a specime: that is representative of the worst case provides the criteria around which the package will be evaluated. A Contents Description Report that will summarize liquid sourceterm parameters and identify a single bounding source term or source-term parameter is scheduled for completion by August 1994.

Figure 2 shows the proposed HALPAK operating sequence. A (Facility) Load-In/Load-Out Interface Report is scheduled for completion by September 1994. This report will supplement the report describing the cask contents in order to establish the actual operating sequence necessary to safely handle and transport liquid specimens offsite. The interface report will delineate where the package operating sequence begins and ends, how to remove a tank specimen at a site, and how to deposit the specimen at an analytical laboratory. In addition, to the maximum extent possible, all the issues requiring resolution (Figure 2) will be addressed.

This preliminary PDC will be revised to reflect the final need, final cask selection, final source term, specimen volume, and retrofitted (1iquid) cask operation before a final design services purchase requisition is issued. To begin design control, the revised PDC document revision number will be changed to reflect the current level of revision. A revision to the $C O C$ for the cask body chosen for HALPAK retrofitting will be required to approve the different payload. For the purposes of this preliminary PDC, the cask body shall be referenced as $X X X-Y$. This symbol will be revised when the cask system has been selected.

\subsection{PURPOSE AND SCOPE}

The purpose and scope of the final PDC shall be as follows:

- Describe the $X X X-Y: \neg S^{\prime}{ }^{\prime}$ and components used for HALPAK retrofitting.

- Describe the payload proposed for the $X X X-Y$.

- DEfine the design criteria for the primary containment vessel.

- Define the HALPAK operating sequence.

- Define the revised and/or additional analyses required to perform the SARP amendment. 


\section{DOE/RL-94-52 \\ Revision 0}

Figure 1. Proposed High-Activity Liquid Packaging Cask System Configuration.

$\begin{array}{lll}\text { Sample } & \text { Uquld } & \text { Large } \\ \text { Shipping } & \text { Transportation } & \begin{array}{c}\text { Shlpping } \\ \text { Module }\end{array} \\ \text { Module } & \text { Modules } & \text { Module }\end{array}$
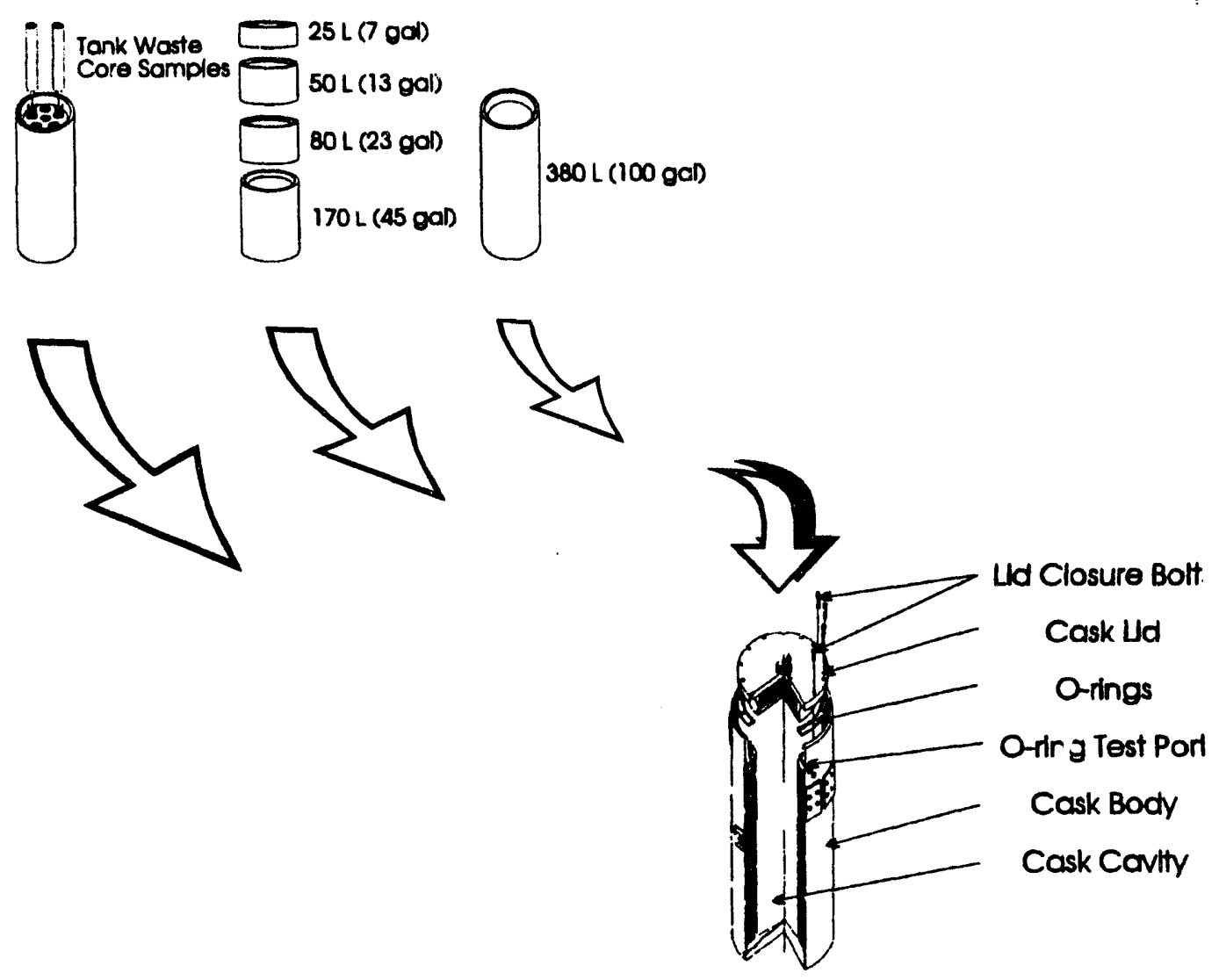

XXX-Y Cask

Cavity Dimensions: Dlameter - $26.5 \mathrm{in}$ Length - 54.0 in 
Figure 2. Proposed High-Activity Liquid Packaging Operating Sequence.

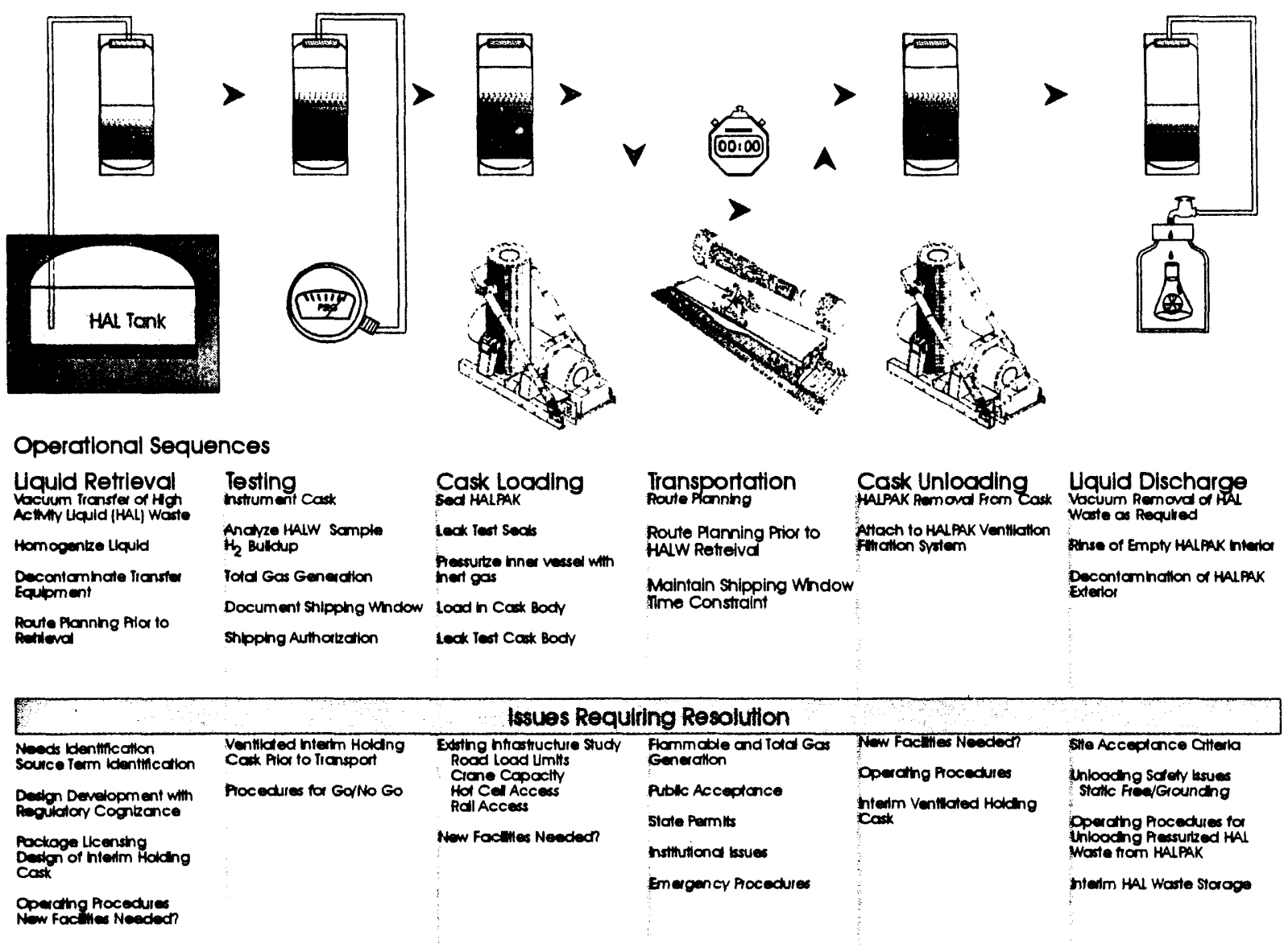


Information and criteria contained in the final PDC will be used as part of the purchase (or lease) specification for the XXX-Y cask body, impact limiters, cask support system, and primary containment vessel, and will also provide the basic information needed to perform an amendment to the SARP for the $X X X-Y$ cask. An amendment to the SARP will be required to describe and evaluate the effect of the new source term, payload configuration, and cask system operation on the original X.XX-Y cask system. Following NRC review and approval of the amended SARP, a revision to the XXX-Y COC will be issued. Offsite shipments of tank liquid specimens in the XXX-Y cask may occur only after the COC revision is issued.

\subsection{JUSTIFICATION}

The scope of tank waste characterization and pretreatment needed at the Hanford Site has indicated a need to use offsite laboratories to handle the increase in significant specimen volumes or to perform testing of new pretreatment processes. Hanford Site tank liquid is more complex than tank liquid at most DOE sites; therefore, it is assumed that packaging designed to satisfy Hanford Site needs will also service most needs at other DOE sites.

As stated in Section 1.1, there are no certified Type-B packagings available for transport of high-activity liquid radioactive specimens in substantial volumes. A cask selection report (to be published in July 1994) will conclude with a recommendation that the XXX-Y cask will be most amenable to retrofitting to enable shipments of large volumes of liquids or multiple specimens of smaller volumes. A comprehensive summary of DOE site liquid specimen transportation needs, as they are known through August 1994, will be provided in the Contents Description Report, further reinforcing the justification presented herein.

\subsection{PACKAGE CONTENTS}

\subsection{PAYLOAD CONFIGURATION}

The original configuration of the $X X X-Y$ package spent fuel contents consists of a removable fuel assembly(ies) basket to laterally and longitudinally support the assembly during transport. The basket will be removed and replaced with a leak-testable or multi-chambered containment vessel. The single or multi-chamber containment vessel will be encased by a shroud. The containment shroud provides structural support for the containment vessel and closure hardware in case of an overpressure event. The shroud also provides shielding to workers as samples are being drawn in the field.

The containment vessel(s) will be a simple, right-circular cylinder with a closure mechanism. The mechanism will be mechanically interlocked to ensure operation in strict accordance with operating procedures. The interlock will ensure the internal pressure will be reduced to ambiont pressure before removal of the specimen from the containment vessial. 
Within the containment vessel, there will be hardware that will extract or recombine flammable gases, primarily hydrogen and nitrous oxide, from the void volume above the liquid. Criticality controls will be present (if ar:alyses determine they are necessary) because it may be possible to extract sufficient fissile material from any underground storage tank at a DOE site. The containment vessel shall provide primary containment, and the cask body shall provide secondary containment. It is possible that a third level of containment could be provided by the containment vessel shroud, but it is not required for the package.

Primary containment shall be defined as the containment vessel; closure hardware (e.g., mechanical device to close the vessel); sealing devices (e.g., 0 -rings); and mechanical joint hardware (e.g., bolts, nuts). The purpose of all components is to hold the liquid during transport. The volume of the containment vessel has not been determined at this time. The containment vessel may be a multi-chambered vessel capable of safely carrying small 250-mL specimens or a single vessel able to transport $50 \mathrm{~L}$ at one time. There will not be absorbent material in the package system.

\subsection{PHYSICAL DESCRIPTION}

Specimen handling is being studied and a (Facility) Load-In/Load-Out Interface Report is being developed. Additional information about specimen size, where the specimen is being drawn from, specific handling requirements or turnaround times, and destination laboratory will be extracted from the Interface and Contents Description Reports.

The following is a description of Hanford Site tank liquid that is representative of design basis liquid at this time.

The tank waste consists of an approximately even distribution of four general physical forms: supernatant, sludge, slurry, and salt cake. Supernatant is the liquid portion of the waste consisting primarily of nitrate and nitrite salts and soluble radionuclides such as cesium-137 $\left({ }^{137} \mathrm{Cs}\right)$. The sludge primarily contains the insoluble components of the waste, which are mostly metal oxides hydroxides, and insoluble radionuclides such as strontium-90 ( $\left.{ }^{\circ 0} \mathrm{Sr}\right)$. Sludge has a consistency ranging from a thick mud (or "peanut butter") to a nearly hard dry substance. Slurry is a mixture of supernatant and sludge with a consistency of thick soup. Salt cake is the result of the evaporation of the supernatant. Therefore, salt cake has the same chemical composition of the supernatant but with a hard crusty consistency.

Table 1 provides a brief summary of the physical characteristics of the tank waste specimens.

\subsection{RADIONUCLIDE COMPOSITION}

Characterization specimens are taken from Hanford Site tanks for analysis to determine the tanks' contents. An estimate of the tanks' contents is required before a sample can be taken. Therefore, existing known radionuclide concentrations have been estimated for dose rate prediction purposes. 
Table 1. Physical Characteristics of Waste.

\begin{tabular}{|l|l|}
\hline \multicolumn{1}{|c|}{ Physical condition } & \multicolumn{1}{c|}{ Description/data } \\
\hline Temperature (in tank) & Near ambient to $82{ }^{\circ} \mathrm{C}$ \\
\hline Density & 0.9 to $3.0 \mathrm{~g} / \mathrm{cc}$ \\
\hline Water percentage & Nearly dry to $50 \%$ \\
\hline Heat load & 0 to $0.2 \mathrm{~W} / \mathrm{L}$ \\
\hline
\end{tabular}

The track radionuclide components (TRAC) database (Jungfleisch 1993) is the most comprehensive source. The TRAC records are primarily based on historical tank discharge and transfer data. However, measurements have shown that the TRAC data can differ substantially from the actual radionuclide levels because of the non-homogeneous nature of the tanks. Because measurements have been made on only a small number of tanks, the TRAC data remain the best available source of the radionuclide inventory of the tanks. Other waste tank data from DOE sites are being gathered to determine the most limiting source term. The results of the source-term study will be consolidated in a Contents Description Report scheduled for completion in August 1994.

Table 2 lists the worst-case concentrations of each radionuclide from the TRAC data, and the activity of that radionuclide for a $500 \mathrm{cc}$ sample. These concentrations are derived by taking the highest predicted concentration of each radionuclide from any one of all the Hanford Site tanks. Because not all radionuclides are at their maximum concentration in the same tank, the actual sample will be less active than this source term. For analys is of the XXX-Y cask, $100 \%$ of the Table 2 concentrations shall be assumed. Table 2 will be appropriately revised in accordance with the Contents Description Report.

\subsection{FISSILE CLASSIFICATION}

Based on the data in Table 2, in volumes greater than approximately $6 \mathrm{~L}$, the contents will be considered fissile because they will have more than $15 \mathrm{~g}$ of fissile material [49 CFR 173.453(a)].

\subsection{CHEMICAL COMPOSITION}

Table 3 provides the non-radioactive source material information from the TRAC database. Table 3 will be appropriately revised in accordance with the Contents Description Report. 
Table 2. Maximum Radionuclide Source Term.

\begin{tabular}{|c|c|c|c|c|c|}
\hline Muclide & $\begin{array}{c}\text { Maximum } \\
\text { concentration } \\
\text { Ci/cc }\end{array}$ & Ci in 500 cc & Nuclide & $\begin{array}{c}\text { Maximum } \\
\text { concentration } \\
\text { Ci/cc }\end{array}$ & $\begin{array}{c}\text { ci in } 500 \text { cc } \\
\text { sample }\end{array}$ \\
\hline${ }^{225} A C$ & $1.04 E-15$ & $5.20 \mathrm{E}-1 ?$ & $1 0 7 \longdiv { P d }$ & $8.81 E-09$ & $4.40 E-06$ \\
\hline 227 Ac & $1.06 E-12$ & $5.28 E-40$ & $210 \mathrm{PO}$ & $3.61 E-18$ & $1.81 E-15$ \\
\hline 241 Am & $8.54 E-06$ & $4.27 E-03$ & 213 Po & $1.04 E-15$ & $5.20 \mathrm{E}-13$ \\
\hline $242 \mathrm{Am}$ & $1.82 E-08$ & 9.11 E-06 & 274Po & $2.23 E-17$ & $1.12 \mathrm{E}-14$ \\
\hline $242 \sqrt{A m}$ & $1.82 E-08$ & $9.11 E-06$ & 215 Po & $1.06 E-12$ & $5.28 E-10$ \\
\hline $243 \mathrm{Am}$ & $8.98 E-09$ & $4.49 E-06$ & $218 \mathrm{PO}$ & $1.79 E-17$ & $8.94 E-15$ \\
\hline $217 \sqrt{A t}$ & $1.04 E-15$ & $5.20 E-13$ & ${ }^{238} \mathrm{Pu}$ & $8.81 E-07$ & $4.40 \mathrm{E}-04$ \\
\hline $210_{B i}$ & $4.05 E-18$ & $2.03 E-15$ & $239 \mathrm{Pu}$ & $1.32 E-05$ & $6.61 E-03$ \\
\hline $211_{8 i}$ & $1.06 E-12$ & $5.28 \mathrm{E}-10$ & $240 \mathrm{Pu}$ & 3.52 E-06 & $1.76 \mathrm{E}-03$ \\
\hline $213 \mathrm{Bi}$ & $1.38 E-15$ & $6.91 E-13$ & $241_{\mathrm{Pu}}$ & 4.40 E-05 & $2.20 E-02$ \\
\hline $214 \mathrm{Bi}$ & $1.79 E-17$ & $8.94 E-15$ & $223_{\mathrm{Ra}}$ & $1.06 E-12$ & $5.28 E-10$ \\
\hline${ }^{14} \mathrm{c}$ & $3.96 E-06$ & $1.98 E-03$ & ${ }^{2} 25 \mathrm{Ra}$ & $1.04 E-15$ & $5.20 E-13$ \\
\hline $242 \mathrm{~cm}$ & 9.25 E-09 & $4.62 \mathrm{E}-06$ & $226_{\mathrm{Ra}}$ & $1.79 E-17$ & $8.94 E-15$ \\
\hline${ }^{244} \mathrm{~cm}$ & 6.16 E-08 & $3.08 \mathrm{E}-05$ & ${ }^{106} \mathrm{Ru}$ & $2.64 E-07$ & $1.32 E-04$ \\
\hline $245 \mathrm{~cm}$ & $3.52 \mathrm{E}-12$ & 1.76 E-09 & ${ }^{126} \mathrm{sb}$ & $2.64 E-06$ & $1.32 E-03$ \\
\hline${ }^{60} \mathrm{Co}$ & 7.66 E-07 & 3.83 E-04 & $126 m_{s b}$ & $2.64 E-06$ & $1.32 E-03$ \\
\hline${ }^{135} \mathrm{cs}$ & 1.32 E-08 & $6.61 E-06$ & 79 se & 8.81 E-08 & $4.40 \mathrm{E}-05$ \\
\hline $137 \mathrm{Cs}^{137 \mathrm{~m}_{\mathrm{Ba}}}$ & $4.40 E-03$ & $2.20 E+00$ & ${ }^{15 T} \mathrm{Sm}$ & $2.64 E-03$ & $1.32 E+00$ \\
\hline $221_{\mathrm{Fr}}$ & $1.04 E-15$ & $5.20 E-13$ & ${ }^{6} \mathrm{sn}$ & $2.64 E-06$ & $1.32 \mathrm{E}-03$ \\
\hline $223 \mathrm{Fr}$ & $1.59 E-14$ & $7.93 E-12$ & ${ }_{90} \mathrm{Sr} / 90^{4}$ & $3.96 E-01$ & $1.98 E+02$ \\
\hline $129_{1}$ & $4.40 \mathrm{E}-09$ & $2.20 \mathrm{E}-06$ & ${ }^{99} \mathrm{TC}$ & $2.64 E-06$ & $1.32 E-03$ \\
\hline $83 m_{\mathrm{wb}}$ & 8.82 E-06 & $4.41 E-03$ & 227 Th & $1.06 \mathrm{E}-12$ & $5.28 E-10$ \\
\hline $63 \mathrm{Mi}$ & $8.81 E-05$ & $4.40 E-02$ & ${ }^{229} \mathrm{Th}$ & $1.04 E-15$ & $5.20 E-13$ \\
\hline 237 Np & $5.28 \mathrm{E}-09$ & $2.64 E-06$ & ${ }^{230} \mathrm{Th}$ & $4.40 \mathrm{E}-15$ & $2.20 \mathrm{E}-12$ \\
\hline $239_{\mathrm{Mp}}$ & $8.10 \mathrm{E}-09$ & $4.05 E-06$ & ${ }^{231} \mathrm{Th}$ & 4.06 E-09 & $2.03 E-06$ \\
\hline $231_{\mathrm{Pa}}$ & $2.38 E-12$ & $1.19 E-09$ & $234 \mathrm{Th}$ & $8.13 \mathrm{E}-08$ & $4.06 \mathrm{E}-05$ \\
\hline $233 \mathrm{~Pa}$ & $5.28 E-09$ & $2.64 E-06$ & $207 \mathrm{TI}$ & $1.06 E-12$ & $5.28 \mathrm{E}-10$ \\
\hline $23411 \mathrm{pa}$ & $8.13 E-08$ & $4.06 \mathrm{E}-05$ & $233 u$ & $7.14 \mathrm{E}-13$ & $3.57 E-10$ \\
\hline${ }^{209} \mathrm{~Pb}$ & $1.04 E-15$ & $5.20 \mathrm{E}-13$ & $234 \mathrm{u}$ & $4.40 \mathrm{E}-11$ & $2.20 \mathrm{E}-08$ \\
\hline $210 \mathrm{~Pb}$ & $4.05 E-18$ & $2.03 E-15$ & $235 \mathrm{u}$ & 4.06 E-09 & $2.03 \mathrm{E}-06$ \\
\hline $211_{\mathrm{Pb}}$ & $1.06 \mathrm{E}-12$ & $5.28 E-10$ & $238 \mathrm{u}$ & $8.13 \mathrm{E}-0 \mathrm{~B}$ & 4.06 E-05 \\
\hline $214 \mathrm{~Pb}$ & $1.79 E-17$ & 8.94 E-15 & $932 r$ & $1.32 E-05$ & $6.61 E-03$ \\
\hline
\end{tabular}


Table 3. Maximum Concentrations of Non-Radioactive Materials.

\begin{tabular}{|c|c|c|c|c|c|}
\hline Const i tuent & $\begin{array}{l}\text { Maximum } \\
\text { mole/L }\end{array}$ & $\underset{\text { cc }}{\operatorname{Maximum} \text { mole/500 }}$ & Const i tuent & $\underset{\text { moximum }}{\text { Max } / L}$ & $\begin{array}{c}\text { Maximum } \\
\text { mole/500 cc }\end{array}$ \\
\hline Ag & $3.52 E-10$ & $1.76 E-10$ & $\mathrm{Hg}$ & 0.00 & 0.00 \\
\hline Al & $3.08 E+01$ & $1.54 E+01$ & $K$ & 3.30 E-01 & $1.65 E-01$ \\
\hline $8 a$ & $8.89 E-03$ & $4.45 E-03$ & La & 1.57 E-02 & $7.85 E-03$ \\
\hline $8 i$ & $5.28 E+00$ & $2.64 E+00$ & Mn & 3.99 E-01 & 1.99 E-01 \\
\hline $\mathrm{C}_{2} \mathrm{H}_{3} \mathrm{O}_{3}$ & 3.52 E-02 & 1.76 E-02 & $\mathrm{NO}_{2}$ & $8.81 E+00$ & $4.40 E+00$ \\
\hline $\mathrm{C}_{6} \mathrm{H}_{5} \mathrm{O}_{7}$ & $2.20 E+00$ & $1.10 E+00$ & $\mathrm{NO}_{3}$ & $9.20 E+01$ & $4.60 E+01$ \\
\hline $\mathrm{CO}_{3}$ & $3.52 E+00$ & $1.76 E+00$ & $\mathrm{Ma}$ & $9.20 E+01$ & $4.60 \mathrm{E}+01$ \\
\hline $\mathrm{C}_{2} \mathrm{O}_{4}$ & 0.00 & 0.00 & $\mathrm{Ni}$ & 2.48 E-01 & $1.24 E-01$ \\
\hline Ca & $4.13 E-01$ & 2.06 E-01 & $\mathrm{OH}$ & $4.41 E+01$ & $2.20 E+01$ \\
\hline cd & 0.00 & 0.00 & $\mathrm{PC}_{4}$ & $5.28 E+00$ & $2.64 E+00$ \\
\hline Ce & 1.83 E-03 & 9.15 E- 04 & $\mathrm{~Pb}$ & 9.97 E-02 & $4.98 E-02$ \\
\hline $\mathrm{Cl}$ & 1.13 E-09 & $5.66 E-10$ & $\mathrm{SeO}_{4}$ & 0.00 & 0.00 \\
\hline $\mathrm{Cr}$ & $3.96 E+00$ & $1.98 E+00$ & $\mathrm{SiO}_{3}$ & $9.32 \mathrm{E}+00$ & $4.66 E+00$ \\
\hline EDTA & 5.28 E-02 & $2.64 E-02$ & Sn & 0.00 & 0.00 \\
\hline $\mathbf{F}$ & $5.15 E+00$ & $2.57 E+00$ & $\mathrm{SO}_{4}$ & $1.13 \mathrm{E}+00$ & $5.66 E-01$ \\
\hline Fe & $4.42 E+00$ & $2.21 E+00$ & Sr & $1.65 E-02$ & 8.27 E-03 \\
\hline $\mathrm{Fe}(\mathrm{CN})_{6}$ & $1.24 E-01$ & 6.20 E-02 & $100_{4}$ & 0.00 & 0.00 \\
\hline HEDTA & 8.81 E-02 & 4.40 E-02 & 2ro & $1.59 E+00$ & $7.93 E-01$ \\
\hline
\end{tabular}

EDTA = Ethylenediaminetetraacetic acid

HEDTA $=\mathrm{N}$-(hydroxyethyl)-ethylenediaminetriacetic acid

\subsection{FACILITY OPERATIONS}

\subsection{ORIGINATING FACILITY}

Exact originating facilities at various DOE sites for the HALPAK specimens are being studied and comprehensively profiled in the (Facility) Load-In/Load-Out Interface Report. Each of these originating facilities has physical (e.g., hot cell opening dimensions, crane capacity, floor loading) and operational (e.g., personnel exposure limitations, how sampling is performed) limitations that must be addressed by the HALPAK design. For example, the originating facilities at the Hanford Site will be the 222-S and 325 Laboratories for waste characterization specimens. Core specimens are typically taken in the tank farms via a core sampler device attached to a drill string. The core sampler device will be transferred to the laboratory in an onsite transfer container. At the laboratory, the core sampler device will be extracted from the container into a hot cell, and the sample extruded into either a $250-\mathrm{mL}$ or $500-\mathrm{mL}$ sample jar. The pass-through doors for the individual hot cells at the 222-S and 325 Laboratories vary, but the most limiting passage dimensions are nominally $23-\mathrm{cm}$ wide by $33-\mathrm{cm}$ high. 
DOE/RL-94-52

Revision 0

\subsection{RECEIVING FACILITY}

Exact receiving facilities of tank specimens are being studied and shall be comprehensively profiled in the (Facility) Load-In/Load-Out Interface Report. Each of these receiving facilities has limitations similar to those of the originating facilities such as physical (e.g., hot cell opening dimensions, crane capacity, floor loading) and operational (e.g., personnel exposure limitations, how sampling is performed) limitations that must be addressed by the HALPAK design. For example, the waste characterization samples' primary receiving facility will be the Chemical Processing Plant (CPP) located at the Idaho National Engineering Laboratory (INEL) Site. The 222-S and 325 Laboratories may al so be considered as receiving facilities, as specimens may be returned from INEL. The unloading of the $X X X X-Y$ cask is the reverse of that specified above for the originating facilities. The CPP hot cell facility has a $13,600-\mathrm{kg}$ monorail crane. Its minimum hot cell passthrough dimensions are $30-\mathrm{cm}$ wide by $46-\mathrm{cm}$ high.

\subsection{PACKAGING/TRANSPORT SYSTEM DESIGN CRITERIA}

\subsection{GENERAL}

The $X X X-Y$ cask system will consist of the following major components:

- $X X X-Y$ cask body (secondary containment) and cask supports

- Containment vessel (primary containment) with shroud

- $X X X-Y$ impact limiters.

With the exception of the spent fuel basket, all the $X X X-Y$ components will be in their "as-1icensed" configuration described in an XXX-Y COC and an SARP. The containment vessel, with shroud, will replace the spent fuel basket used in the currently licensed version of the $X X X-Y$. Note that the new payload and the use of the containment vessel and shroud will require an amendment to the SARP, as described in Section 5.1.

\section{$4.2 X X X-Y$ CASK}

Final selection of the spent fuel cask body most amenable to retrofitting will be presented in the Cask Selection Report.

Structural, thermal, shielding, and criticality final design analyses of the cask body loaded with a filled containment vessel shall use the same allowable stress criteria to be presented in an SARP of the cask selected for liquid transport retrofitting. This will ensure that the loads imparted on the cask body structure are shown to be less than the loads from the original spent fuel assemblies for which the cask was designed. 
DOE/RL-94-52

Revision 0

\subsection{CONTAINMENT VESSEL AND SHROUD}

\subsubsection{General Description and Loading Configuration}

The purpose of the fiscal year 1994 activities is to establish one primary feasible HALPAK package design. A second design will ailso be developed, but to a lesser extent. The containment vessel (including closure hardware) and shroud are conceptual design activities currently being completed based on data available io date. Meeting(s) with the DOE/NRC regulatory authorities to discuss the conceptual packaging designs will determine the design with the greatest licensing potential. This section will be completely revised based on information and corments from regulatory authorities during design review meetings at which several conceptual designs are to be presented.

\subsubsection{Construction Materials}

The primary containment components shall be designed to the intent of the American Society of Mechanical Engineers (ASME) Boiler and Pressure Vessel Code, Section III, Division 1 (ASME 1992). The containment vessel shroud or overpressure shroud shall be designed to the Boiler and Pressure Vessel Code, Section VIII, Division 1. This graded approach to Code application is intended to reduce fabrication costs by applying code rules corresponding to how critical the component is to the safety of the package.

Materials used in the fabrication of the containment vessel and shroud are to be selected from those presented in the respective Boiler and Pressure Vessel Code (ASME 1992) appendix containing the material properties. The material of construction shall be selected to ensure that there will be no significant chemical, galvanic, or other reaction among the packaging components or between the packaging components and the package contents during the specified service life (see Section 4.3.9) of the packaging. Materials suitable for ease of decontamination shall be considered.

\subsubsection{Dimensions and Volumes}

This section will be completed in the revised PDC.

\subsubsection{Weight of Contents}

This section will be completed in the revised PDC.

\subsubsection{Closure Design and Venting}

This section will be completed in the revised PDC. 


\subsubsection{Shielding}

This section will be completed in the revised PDC. The dose rate consequence cask with the liquid contents must be designed to be less than that of the cask with solid fuel assemblies.

\subsubsection{Lifting Attachments}

Lifting attachments on the containment vessel and shroud shall be designed to enable safe lifting by hand, manipulator, or crane hook. The lifting attachment should fold down, or be recessed, to allow stable stacking of the containment vessels. The lifting attachment structure shall be designed to meet a minimum safety factor of 3 to yicld strength, and 5 to ultimate strength of the material.

\subsubsection{Gas Mitigation Hardware}

This section will be completed in the revised PDC.

\subsubsection{Service Life}

This section will be completed in the revised PDC.

\subsubsection{Decontamination}

This section will be completed in the revised PDC.

\subsection{TRANSPORT SYSTEM}

\subsubsection{General}

This section will be completed in the revised PDC.

\subsubsection{Tiedowns}

This section will be completed in the revised PDC.

\subsection{GENERAL REQUIREMENTS}

\subsection{TRANSPORTATION SAFETY}

This section will be completed in the revised PDC. 
An amendment to the SARP for the $X X X-Y$ cask will be required to describe and evaluate the new source term and payload configuration. Following NRC review and approval of the amended SARP, a revision to the $X X X-Y$ COC will be issued. Offsite shipments of tank waste specimens in the $X X X-Y$ cask may take place only after the COC revision is issued.

The amendment will analyze the effects of the new payload and the use of the primary vessel on the containment, shielding, and subcriticality ispects of the packaging, under normal transport conditions and hypothetical accident conditions, including a hypothetical overpressure incident. More specificaliy:

a. The larger liquid volume will require a more in-depth analysis of containment and the hydrogen gas generation rates. Suitable controls in the revised $C O C$ (i.e., limited shipping times) may be mandated as a result of the analysis.

b. The higher-activity source term specified in Section 2.3 will require a revision to the thermal shielding and criticality calculations in the approved SARP. No design changes to the $X X X-Y$ shielding will be allowed.

c. Appropriate changes to Section 1.0, General Information, and Section 7.0, Operating Procedures, of the SARP will be needed to reflect the new source term and the use of the containment vessel. Also, changes to the Quality Assurance subsection (see Section 1.0) of the SARP for the $X X X-Y$ cask may be needed to reflect the new payload configuration.

d. Revised analyses demonstrating that the new payload will not invalidate structural analyses in the original SARP for the $X X X-Y$ cask will be provided.

\subsection{AS LOW AS REASONABLY ACHIEVABLE (ALARA)}

Design features of the containment vessels and ancillary equipment shall be consistent with the requirements of WHC-CM-4-11, ALARA Program Manual. Exposure of personnel to radiological and other hazardous materials associated with the loading, closure, unloading, and maintenance of the $X X X-Y$ cask and containment vessel and supporting hardware shall be minimized.

\subsection{QUALITY ASSURANCE}

Design, fabrication, testing, verification, and operational activities for the $X X X-Y$ cask and its components shall be in accordance with the Quality Assurance subsection (see Section 1.0) of the SARP for the XXX-Y cask. 


\subsection{PACKAGING AND SHIPPING}

General requirements for the packaging and shipping of hazardous radioactive materials shall be in accordance with Site-specific documents. Further packaging and shipping information can be provided once the shipping and receiving sites have been identified.

\subsection{MAINTENANCE}

Ease and minimization of maintenance shall be considered in the design of the containment vessel and supporting hardware. Vendor spare parts and maintenance data, if applicable, shall be provided for equipment specified in the design. Special tools required to operate, replace, or repair $X X X-Y$ cask components shall be identified as part of the project.

\section{6. $\cap$ REFERENCES}

49 CFR 173, "Shippers-General Requirements for Shipments and Packaging," Code of Federal Regulations, as amended.

ASME, 1992, Boiler and Pressure Vessel Code, American Society of Mechanical Engineers, New York, New York.

Jungfleisch, F. M., 1993, Preliminary Estimation of the Waste Inventories in Hanford Tanks Through 1980, WHC-SD-WM-TI-057, Westinghouse Hanford Company, Richland, Washington.

WHC-CM-4-11, ALARA Prograi.. Manual, Westinghouse Hanford Company, Richland, Washington.

\subsection{GLOSSARY}

\section{ABBREVIATIONS AND ACRONYMS}

$\begin{array}{ll}\text { ALARA } & \text { as low as reasonably achievable } \\ \text { ASME } & \text { American Society of Mechanical Engineers } \\ \text { COC } & \text { Certificate of Compliance } \\ \text { CPP } & \text { Chemical Processing Plant } \\ \text { DOE } & \text { U.S. Department of Energy } \\ \text { EDTA } & \text { Ethylenediaminetetraacetic acid } \\ \text { HALPAK } & \text { High-Activity Liquid Packaging } \\ \text { HEDTA } & \text { N-(hydroxyethyl)-ethylenediaminetriacetic acid } \\ \text { INEL } & \text { Idaho National Engineering Laboratory } \\ \text { NRC } & \text { U.S. Nuclear Regulatory Commission } \\ \text { PDC } & \text { Packaging Design Criteria } \\ \text { TRAC } & \text { track radionuclide components } \\ \text { SARP } & \text { Safe Analysis Report for Packaging }\end{array}$




\section{DOE/RL-94-52 \\ Revision 0 \\ DISTRIBUTION}

Number of Copies

OFFSITE

3

U.S. Department of Energy-Headquarters 12800 Middlebrook Road

Germantown, Maryland 20874

L. G. Blalock

EM 261

M. J. Conroy

EM 261

E. B. McNeil

EM 261

\section{ONSITE}

3

U.S. Department of Energy,

Richland Operations office

R. F. Guercia

S. K. Moy

Public Reading Room

R3-80

R3-80

Al-65

1

Pacific Northwest Laboratory

Technical Files

K1-11

18

Westinghouse Hanford Company

L. R. Burks

G6-14

N. M. Meinert

T. L. Wardlow (6)

G2-02

Central Files

G2- 02

Document Processing and Distribution (2)

Information Release Administration (3)

L8-04

L8-15

A3-36

Distr-1 

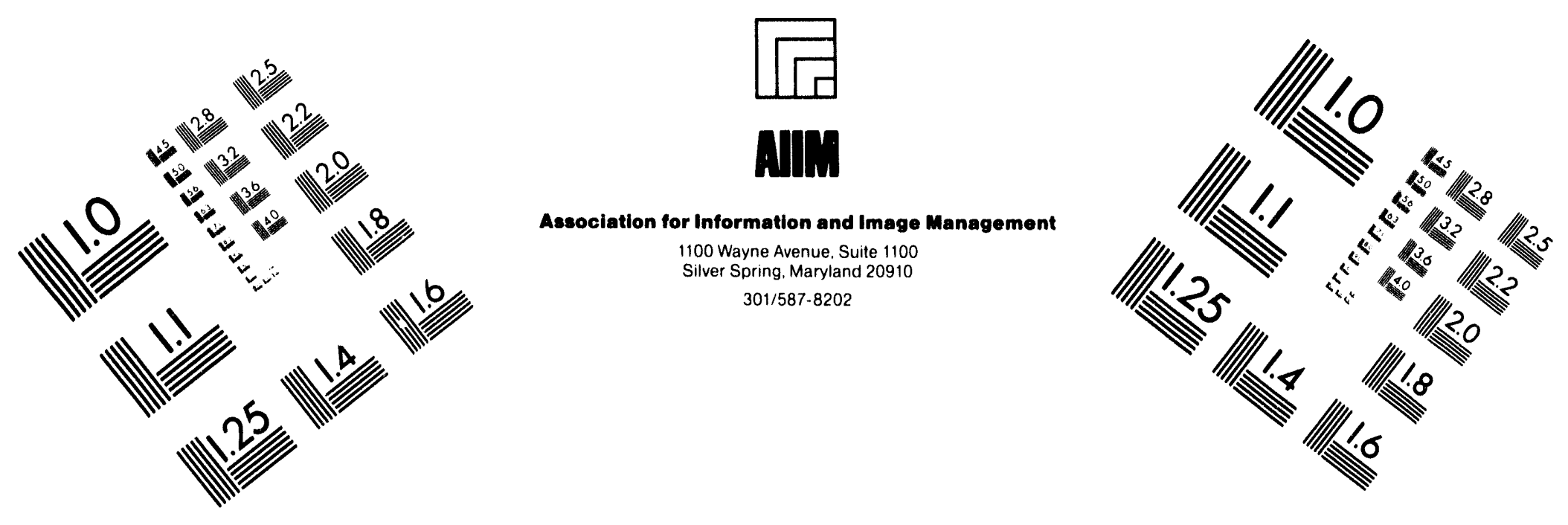

\section{Centimeter} L

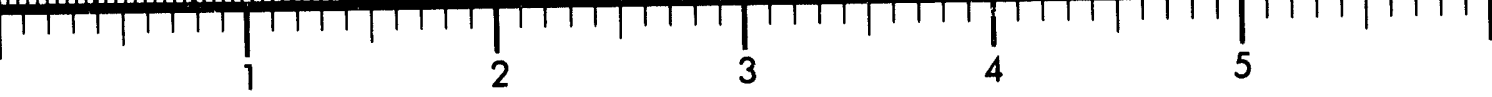
Inches
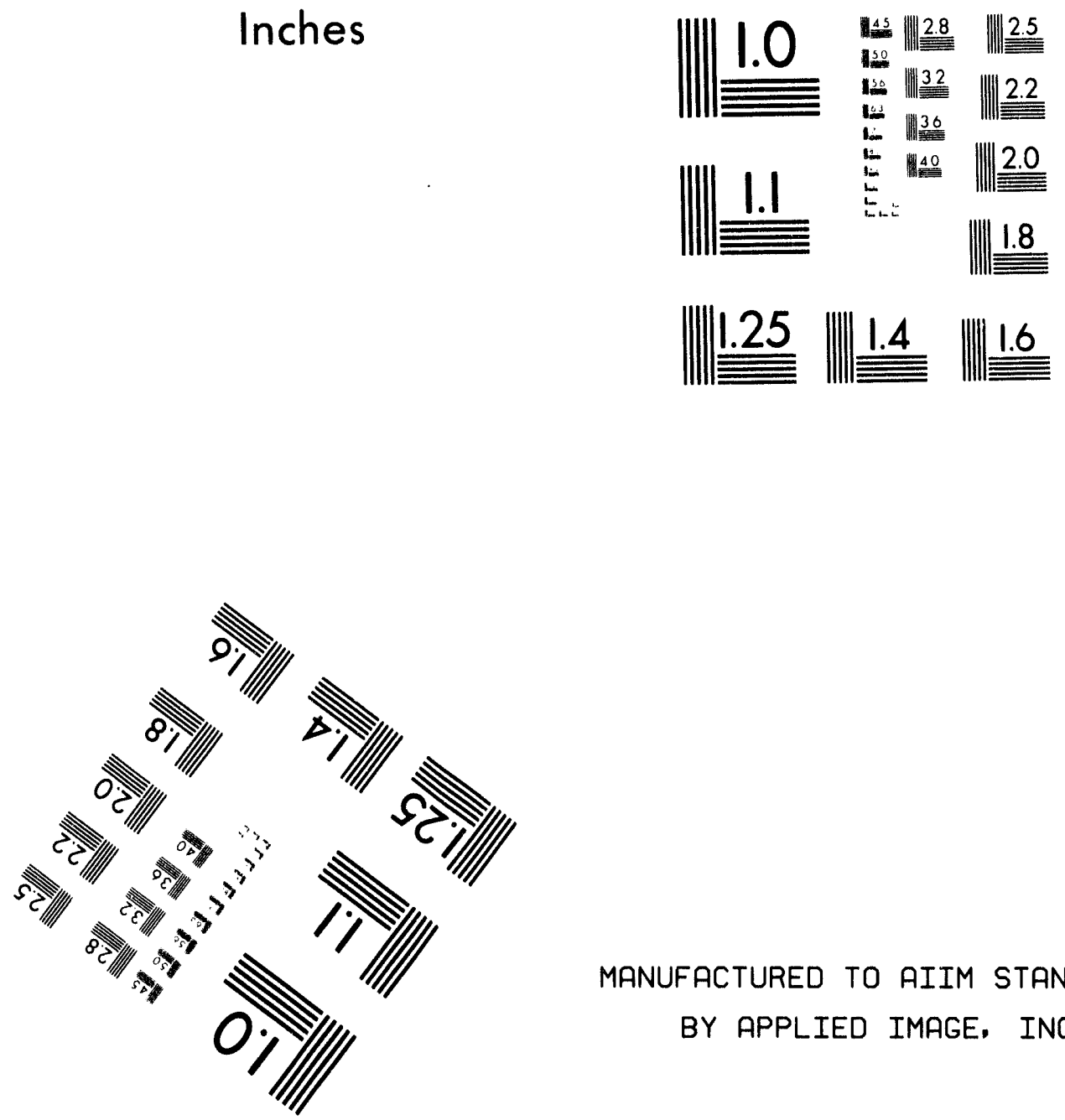

MANUFACTURED TO AIIM STANDARDS

BY APPLIED IMAGE, INC.

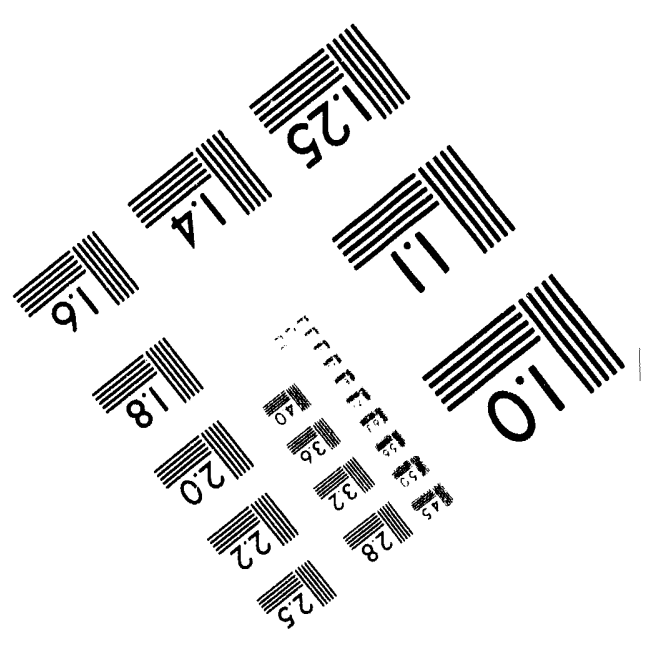




\section{$-$}



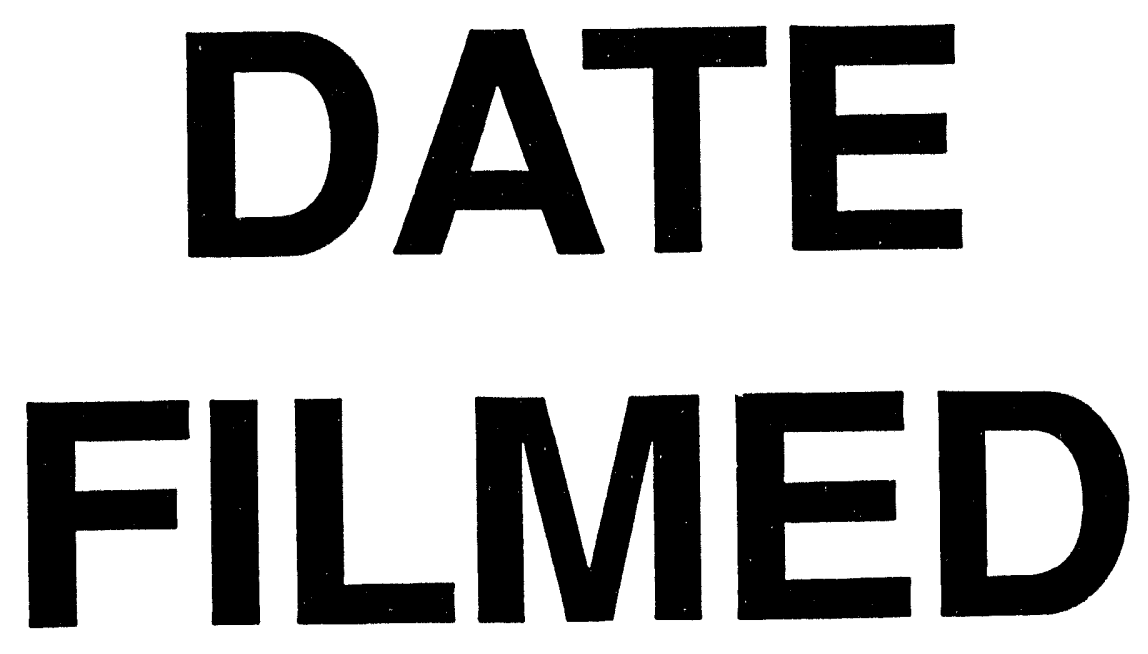

$12 / 13 / 94$
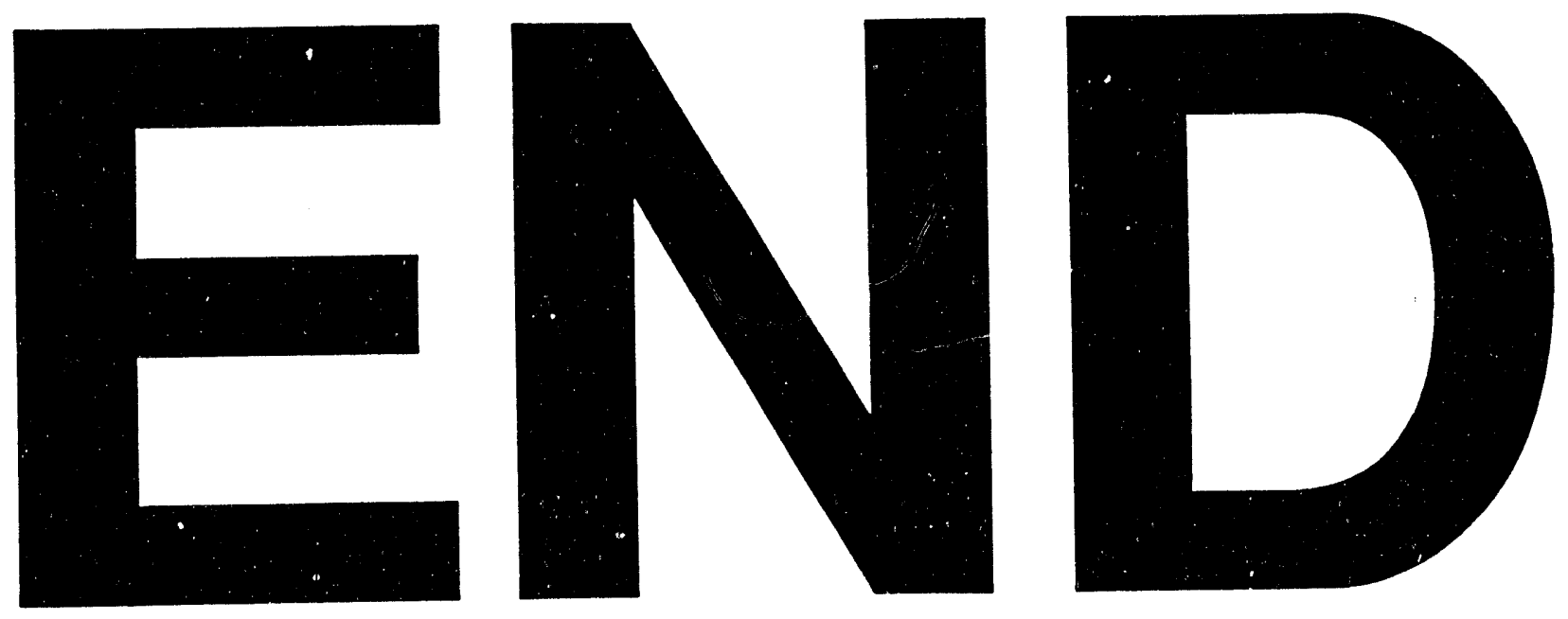